\title{
Transformation of raindrops characters on natural rainfalls
}

\author{
YANG Er, BAO Hongzhe, CHEN Li, NI Yongxin, HUANG Jing, ZUO Zhongguo, LV \\ Xizhi
}

Key Laboratory of Soil and Water Loss Process and Control on the Loess Plateau. MWR, Yellow River Institute of Hydraulic Research, Zhengzhou 450003, China

shenzz@139.com

Keywords: natural rain; simulate rain; rain intensity; rain amount

Abstract: In this paper, we adopted natural rain experiment method to study the transformation of the change of raindrop speed and diameter with time and the results indicated that the rain intensity change strongly with time at the natural rainfall. At the natural rain,the raindrop speed mainly at $0.8-5.8 \mathrm{~m} / \mathrm{s}$ in different time 20130529 natural rain, it has wave crest were $3.4 \mathrm{~m} / \mathrm{s}$. In natural rainfall, the $0.125 \mathrm{~mm}$ diameter raindrop speed were about at $0.8-5 \mathrm{~m} / \mathrm{s}$, the $0.25 \mathrm{~mm}$ diameter raindrop speed were about at $1-5.8 \mathrm{~m} / \mathrm{s}$, the $0.375 \mathrm{~mm}$ diameter raindrop speed were about at $1-4.2 \mathrm{~m} / \mathrm{s}$, the $0.5 \mathrm{~mm}$ diameter raindrop speed were about at $2.2-3.4 \mathrm{~m} / \mathrm{s}$, the $0.75 \mathrm{~mm}$ diameter raindrop speed were about at $3.4-4.2 \mathrm{~m} / \mathrm{s}$, the $1 \mathrm{~mm}$ diameter raindrop speed were about at $3.4-4.2 \mathrm{~m} / \mathrm{s}$, the $1.25 \mathrm{~mm}$ diameter raindrop speed were about at $3.4 \mathrm{~m} / \mathrm{s}$.

\section{Introduction}

The sediment yield of experiment about soil and water conservation and its process have become the hotspot in the research of the world environments, and many researchers of different countries have done lots of studies on the field, process and effects of soil erosion and obtained rich achievements ${ }^{[1-2]}$. However, severe soil erosion and large silt discharge of the Loess plateau into Yellow River have focused the concern of the world. Have much new approach for soil erosion research, and got many Meaningful results ${ }^{[3-14]}$.but the rainfall similar is a difficult point of soil erosion to simulate on Loess Slope. So, the experiment on runoff plots and simulate rain were be done, hoping to provide basic data closer to real ones, and technical support for the forecasting model of soil erosion in the Loess Plateau.

\section{Method}

\section{Experiment model design}

Experiment was done in the Yellow River Model Base of Yellow River Institute of Hydraulic Research. The model slope degree could adjust from $5^{\circ}-45^{\circ}$, could be used to the artificial rainfall experiment could also be used for scouring experiment. The slope model was done $5 \mathrm{~m}$ length, $3 \mathrm{~m}$ width, and $60 \mathrm{~cm}$ depth. the model will be divided three same parts which $5 \mathrm{~m}$ length, $1 \mathrm{~m}$ width use PVC, to do 3 times repeated experiment. Model have adjustable plank to measure dates, catchments slot ware was lied model under part to collect runoff and sediment.

\section{Experiment Design}

The experiment soil was carried from Mangshan Mountain, particle composition is different (Table 1 ), and soil dry bulk density is about $1.2 \mathrm{~g} / \mathrm{cm}^{3}$. Every experiment has two repeat tests.

Tab1 the percent of grain diameter about soil sample

\begin{tabular}{cccccccc}
\hline grain diameter $(\mathrm{mm})$ & $>1.0$ & $\begin{array}{c}1 \sim \\
0.25\end{array}$ & $\begin{array}{c}0.25 \sim \\
0.05\end{array}$ & $\begin{array}{c}0.05 \sim \\
0.01\end{array}$ & $0.01 \sim 0.005$ & $0.005 \sim 0.001$ & $<0.001$ \\
\hline percent $(\%)$ & 0 & 1.05 & 35.45 & 43.4 & 3.2 & 6.4 & 10.5 \\
\hline
\end{tabular}

\section{Experiment Method}

To fill in $10 \mathrm{~cm}$ thick natural sand on the lower part of the model firstly, and then continue to fill in 
$20 \mathrm{~cm}$ thick loess which carried from Mangshan mountain, use wooden planks to pat the soil, so that its density reached $1.2 \mathrm{~g} / \mathrm{cm}^{3}$, and then put twice $15 \mathrm{~cm}$ thick loess soil samples, controlled bulk density are $1.2 \mathrm{~g} / \mathrm{cm}^{3}$. Laying a $20 \mathrm{~cm}$ long carpet on junction between the steady flow pool and slope for ensuring the wash flow arrive slope steadily. The slope soil should be watering saturation at the beginning of the eve of experiment.

The raindrops characters of natural rainfall were detected by LPM The laser raindrop spectrometer, beside the raindrops velocity, particle size and amount.

When the rainfall is enough big, the runoff will come to the runoff barrel, and then change one barrel every $1 \mathrm{~min}$. Surveying the runoff weight and volume in every barrel to count the erosion and sediment using conversation method. At the same time, determinates the hydrodynamic parameters every $1 \mathrm{~min}$. Finally arrange the dates to analysis the rainfall and slope degree effect on sediment and energy consumption using statistical methods.

\section{Results: The change of raindrop speed and diameter of the natural rain with time}

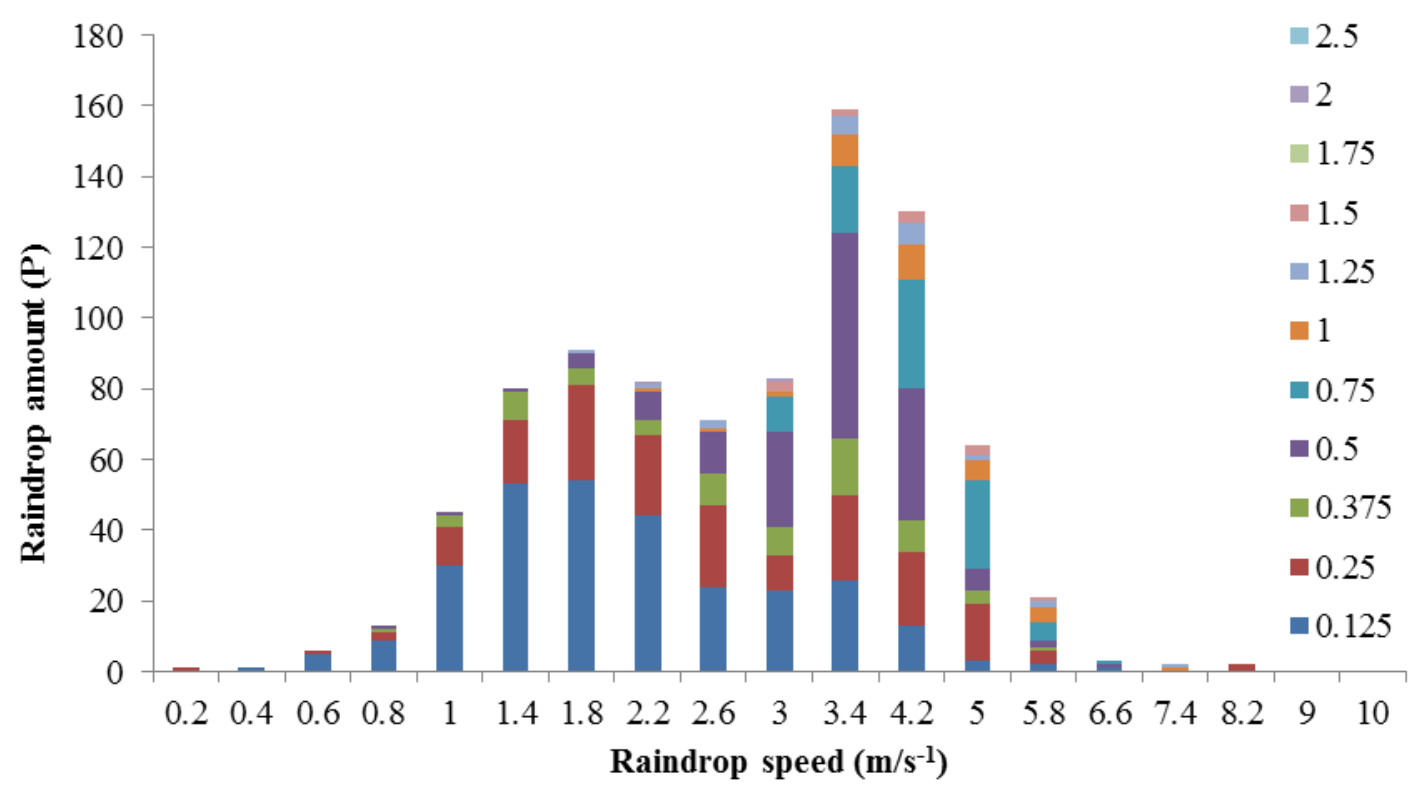

Fig.1 The relation between raindrop speed and diameter by $1 \mathrm{~min}$ of 20130529 natural rain

The relation between raindrop speed and diameter was be analyzed by 1 min of 20130529 natural rain (fig1), the $\mathrm{X}$-axis stand for the raindrop speed and the different colours stand for the different raindrop diameter, the Y-axis stand for the raindrop amount. From the map we can see that the raindrop speed mainly at $0.8-5.8 \mathrm{~m} / \mathrm{s}$ in $1 \mathrm{~min}$, the wave crest was $3.4 \mathrm{~m} / \mathrm{s}$, has 160 same speed raindrop. At the same times, the $0.125 \mathrm{~mm}$ diameter raindrop speed were about at $0.8-4.2 \mathrm{~m} / \mathrm{s}$, the $0.25 \mathrm{~mm}$ diameter raindrop speed were about at $1-5 \mathrm{~m} / \mathrm{s}$, the $0.375 \mathrm{~mm}$ diameter raindrop speed were about at $1.4-4.2 \mathrm{~m} / \mathrm{s}$, the $0.5 \mathrm{~mm}$ diameter raindrop speed were about at $2.2-4.2 \mathrm{~m} / \mathrm{s}$, the $0.75 \mathrm{~mm}$ diameter raindrop speed were about at $3-5 \mathrm{~m} / \mathrm{s}$, the $1 \mathrm{~mm}$ diameter raindrop speed were about at $3.4-4.2 \mathrm{~m} / \mathrm{s}$, the $1.25 \mathrm{~mm}$ diameter raindrop speed were about at $3.4-4.2 \mathrm{~m} / \mathrm{s}$.

The relation between raindrop speed and diameter was be analyzed by $5 \mathrm{~min}$ of 20130529 natural rain (fig2), the $\mathrm{X}$-axis stand for the raindrop speed and the different colours stand for the different raindrop diameter, the $\mathrm{Y}$-axis stand for the raindrop amount. From the map we can see that the raindrop speed mainly at $0.8-5.8 \mathrm{~m} / \mathrm{s}$ in $5 \mathrm{~min}$, the wave crest was $3.4 \mathrm{~m} / \mathrm{s}$, has 280 same speed raindrop. At the same times, the $0.125 \mathrm{~mm}$ diameter raindrop speed were about at $0.8-4.2 \mathrm{~m} / \mathrm{s}$, the $0.25 \mathrm{~mm}$ diameter raindrop speed were about at $1-5 \mathrm{~m} / \mathrm{s}$, the $0.375 \mathrm{~mm}$ diameter raindrop speed were about at $1-4.2 \mathrm{~m} / \mathrm{s}$, the $0.5 \mathrm{~mm}$ diameter raindrop speed were about at $2.2-4.2 \mathrm{~m} / \mathrm{s}$, the $0.75 \mathrm{~mm}$ diameter raindrop speed were about at $3.4-5 \mathrm{~m} / \mathrm{s}$, the $1 \mathrm{~mm}$ diameter raindrop speed were about at $3.4-5 \mathrm{~m} / \mathrm{s}$, the $1.25 \mathrm{~mm}$ diameter raindrop speed were about at $4.2 \mathrm{~m} / \mathrm{s}$. 


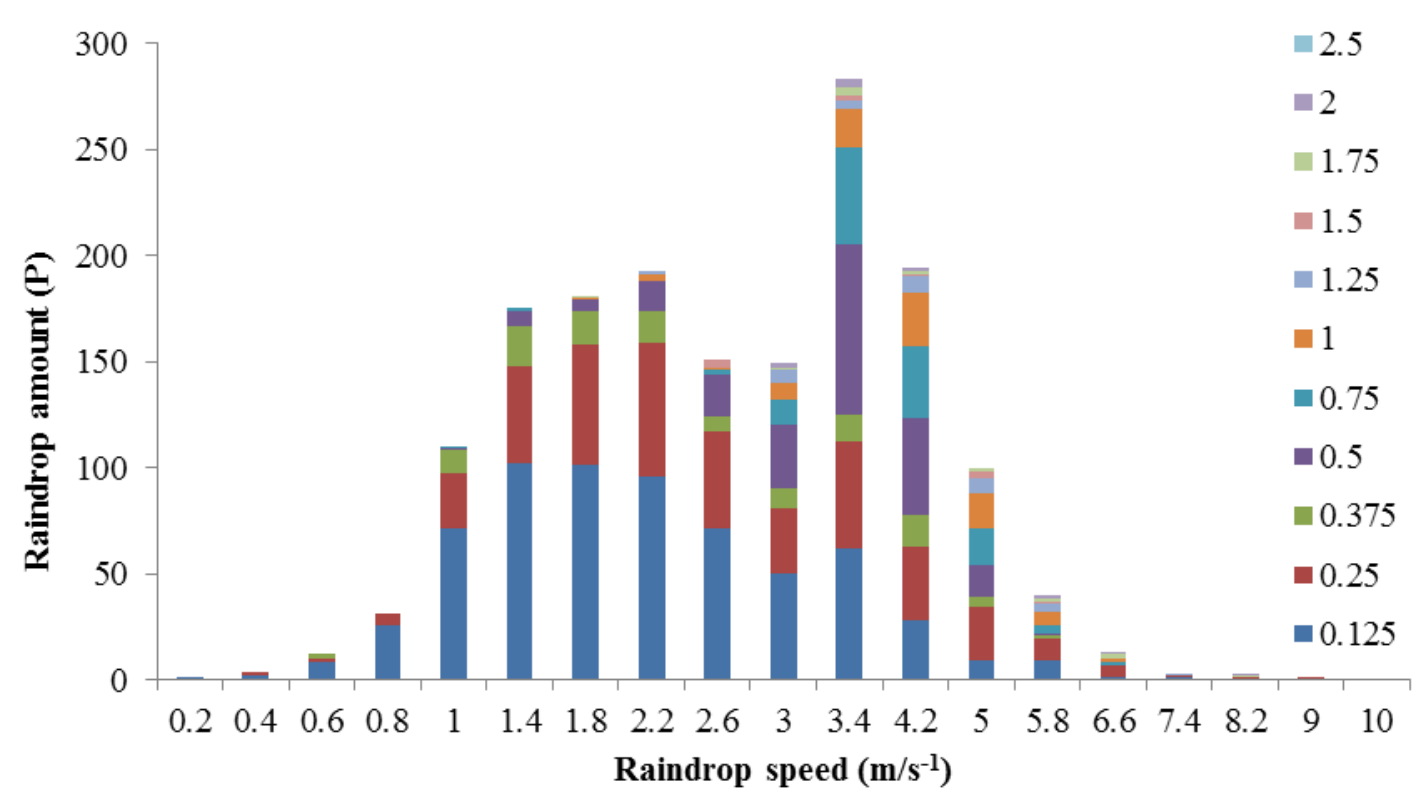

Fig.2 The relation between raindrop speed and diameter by $5 \mathrm{~min}$ of 20130529 natural rain

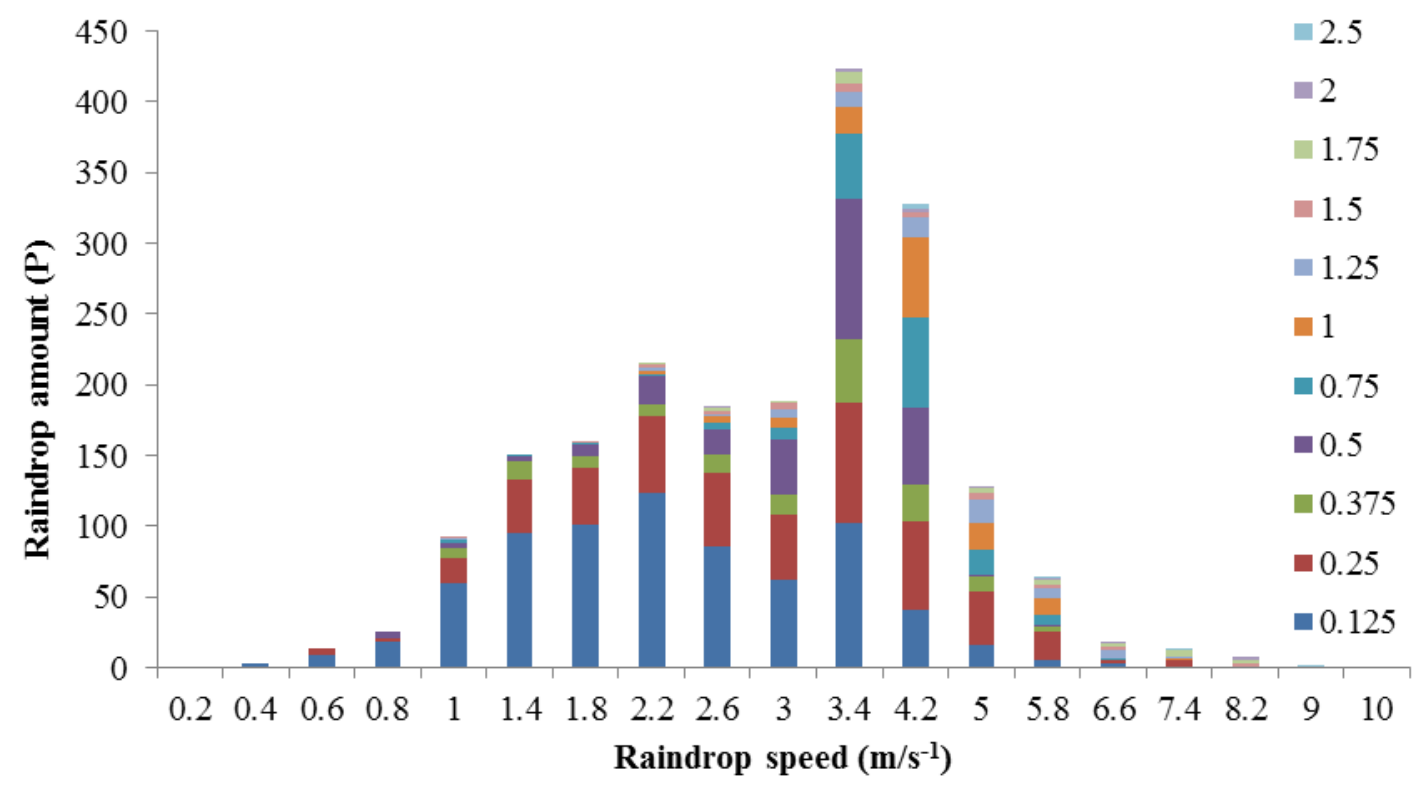

Fig.3 The relation between raindrop speed and diameter by 10min of 20130529 natural rain

The relation between raindrop speed and diameter was be analyzed by $10 \mathrm{~min}$ of 20130529 natural rain (fig3), the $\mathrm{X}$-axis stand for the raindrop speed and the different colours stand for the different raindrop diameter, the Y-axis stand for the raindrop amount. From the map we can see that the raindrop speed mainly at $0.8-5.8 \mathrm{~m} / \mathrm{s}$ in $10 \mathrm{~min}$, the wave crest was $3.4 \mathrm{~m} / \mathrm{s}$, has 420 same speed raindrop. At the same times, the $0.125 \mathrm{~mm}$ diameter raindrop speed were about at $0.8-4.2 \mathrm{~m} / \mathrm{s}$, the $0.25 \mathrm{~mm}$ diameter raindrop speed were about at $1-5.8 \mathrm{~m} / \mathrm{s}$, the $0.375 \mathrm{~mm}$ diameter raindrop speed were about at $1-5 \mathrm{~m} / \mathrm{s}$, the $0.5 \mathrm{~mm}$ diameter raindrop speed were about at $2.2-4.2 \mathrm{~m} / \mathrm{s}$, the $0.75 \mathrm{~mm}$ diameter raindrop speed were about at $3.4-4.2 \mathrm{~m} / \mathrm{s}$, the $1 \mathrm{~mm}$ diameter raindrop speed were about at $3.4-5 \mathrm{~m} / \mathrm{s}$, the $1.25 \mathrm{~mm}$ diameter raindrop speed were about at $4.2-5 \mathrm{~m} / \mathrm{s}$. 


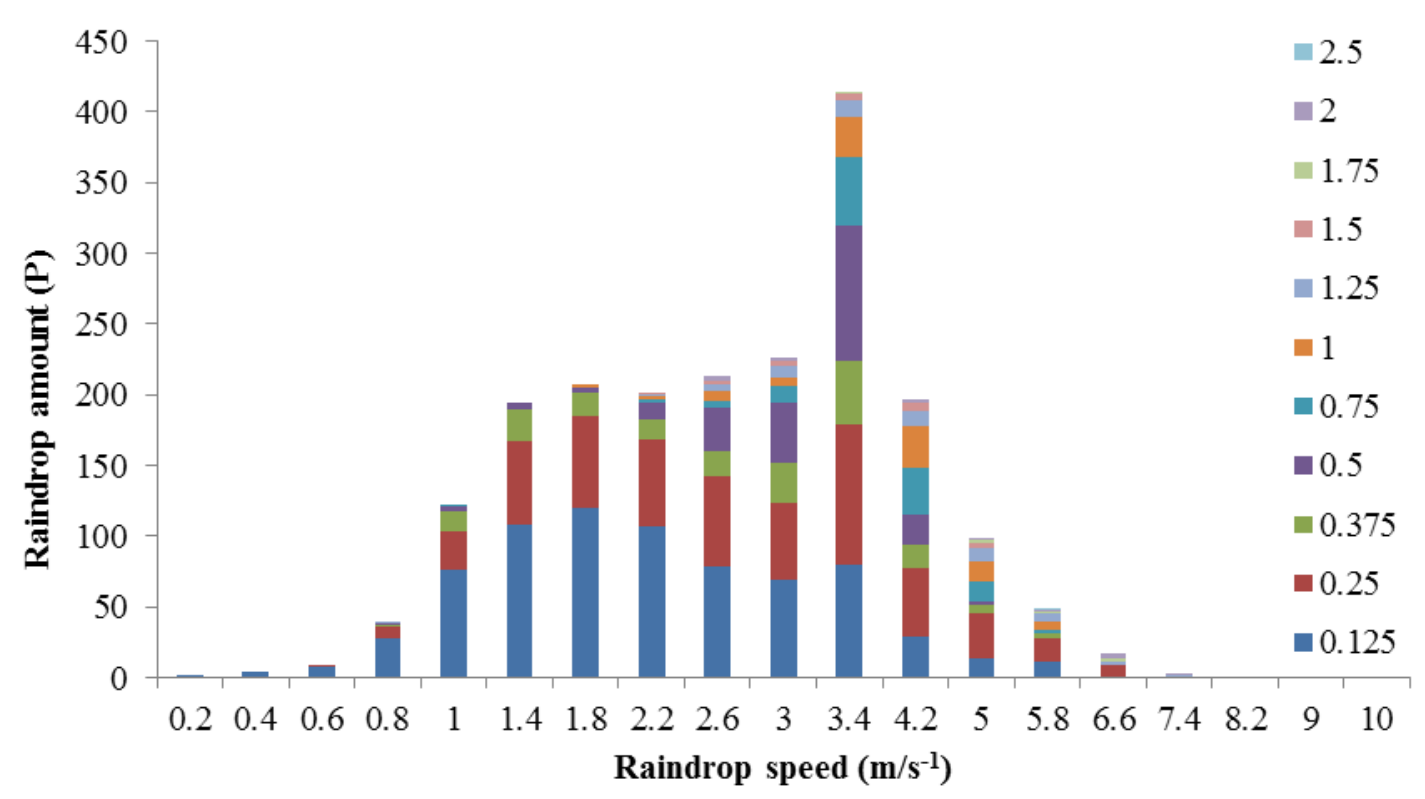

Fig.4 The relation between raindrop speed and diameter by $15 \mathrm{~min}$ of 20130529 natural rain

The relation between raindrop speed and diameter was be analyzed by $15 \mathrm{~min}$ of 20130529 natural rain (fig4), the $\mathrm{X}$-axis stand for the raindrop speed and the different colours stand for the different raindrop diameter, the Y-axis stand for the raindrop amount. From the map we can see that the raindrop speed mainly at $0.8-5.8 \mathrm{~m} / \mathrm{s}$ in $15 \mathrm{~min}$, the wave crest was $3.4 \mathrm{~m} / \mathrm{s}$, has 400 same speed raindrop. At the same times, the $0.125 \mathrm{~mm}$ diameter raindrop speed were about at $0.8-5 \mathrm{~m} / \mathrm{s}$, the $0.25 \mathrm{~mm}$ diameter raindrop speed were about at $1-5.8 \mathrm{~m} / \mathrm{s}$, the $0.375 \mathrm{~mm}$ diameter raindrop speed were about at $1-4.2 \mathrm{~m} / \mathrm{s}$, the $0.5 \mathrm{~mm}$ diameter raindrop speed were about at $2.2-3.4 \mathrm{~m} / \mathrm{s}$, the $0.75 \mathrm{~mm}$ diameter raindrop speed were about at $3.4-4.2 \mathrm{~m} / \mathrm{s}$, the $1 \mathrm{~mm}$ diameter raindrop speed were about at $3.4-4.2 \mathrm{~m} / \mathrm{s}$, the $1.25 \mathrm{~mm}$ diameter raindrop speed were about at $3.4-5 \mathrm{~m} / \mathrm{s}$.

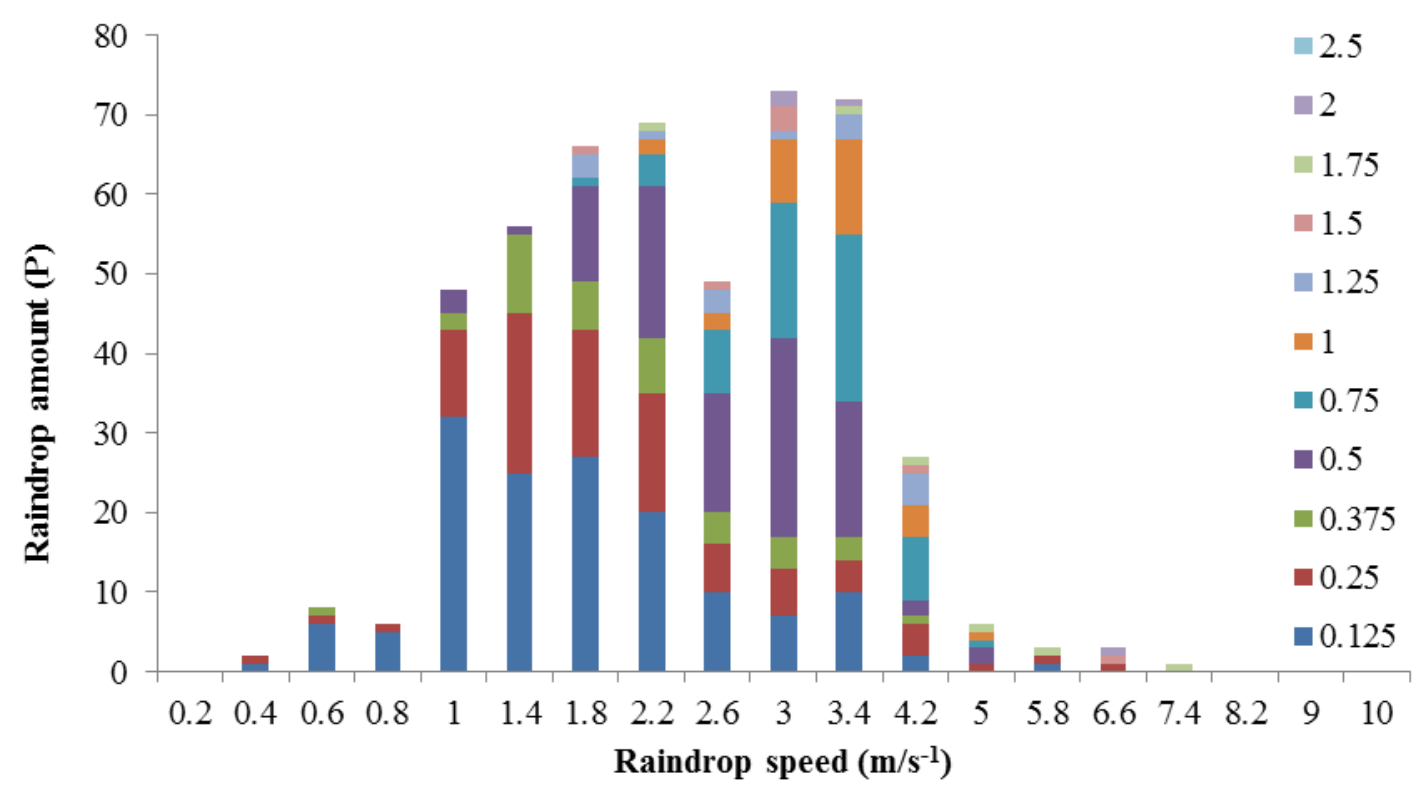

Fig.5 The relation between raindrop speed and diameter by $20 \mathrm{~min}$ of 20130529 natural rain

The relation between raindrop speed and diameter was be analyzed by $20 \mathrm{~min}$ of 20130529 natural rain (fig5), the $\mathrm{X}$-axis stand for the raindrop speed and the different colours stand for the different raindrop diameter, the $\mathrm{Y}$-axis stand for the raindrop amount. From the map we can see that the raindrop speed mainly at $1-4.2 \mathrm{~m} / \mathrm{s}$ in $20 \mathrm{~min}$, the wave crest was $3.4 \mathrm{~m} / \mathrm{s}$, has 70 same speed raindrop. At the same times, the $0.125 \mathrm{~mm}$ diameter raindrop speed were about at $0.6-3.4 \mathrm{~m} / \mathrm{s}$, the $0.25 \mathrm{~mm}$ diameter raindrop speed were about at $1-4.2 \mathrm{~m} / \mathrm{s}$, the $0.375 \mathrm{~mm}$ diameter raindrop speed were about at 
$1.4-3.4 \mathrm{~m} / \mathrm{s}$, the $0.5 \mathrm{~mm}$ diameter raindrop speed were about at $1.8-3.4 \mathrm{~m} / \mathrm{s}$, the $0.75 \mathrm{~mm}$ diameter raindrop speed were about at $2.2-4.2 \mathrm{~m} / \mathrm{s}$, the $1 \mathrm{~mm}$ diameter raindrop speed were about at $3-3.4 \mathrm{~m} / \mathrm{s}$, the $1.25 \mathrm{~mm}$ diameter raindrop speed were about at $3.4-4.2 \mathrm{~m} / \mathrm{s}$.

\section{Conclusions}

1. At the natural rain,the raindrop speed mainly at $0.8-5.8 \mathrm{~m} / \mathrm{s}$ in different time 20130529 natural rain, it has wave crest were $3.4 \mathrm{~m} / \mathrm{s}$.

2. In natural rainfall, the $0.125 \mathrm{~mm}$ diameter raindrop speed were about at $0.8-5 \mathrm{~m} / \mathrm{s}$, the $0.25 \mathrm{~mm}$ diameter raindrop speed were about at $1-5.8 \mathrm{~m} / \mathrm{s}$, the $0.375 \mathrm{~mm}$ diameter raindrop speed were about at $1-4.2 \mathrm{~m} / \mathrm{s}$, the $0.5 \mathrm{~mm}$ diameter raindrop speed were about at $2.2-3.4 \mathrm{~m} / \mathrm{s}$, the $0.75 \mathrm{~mm}$ diameter raindrop speed were about at $3.4-4.2 \mathrm{~m} / \mathrm{s}$, the $1 \mathrm{~mm}$ diameter raindrop speed were about at $3.4-4.2 \mathrm{~m} / \mathrm{s}$, the $1.25 \mathrm{~mm}$ diameter raindrop speed were about at $3.4 \mathrm{~m} / \mathrm{s}$.

\section{Acknowledgment}

We greatly appreciate our group for useful discussions on this subject and all referees for their assistance and laboratory work. This research mainly supported by the Central Public Research Cost (HKY-JBYW-2013-03), Innovation Scientists and Technicians Troop Construction Projects of Henan Province ( 162101510004 ), National Natural Science Foundation of China (41201267), $\mathrm{Xi}$ an university of technology (KFKT-1,KFKT-2).

\section{References}

[1] K.L.Tang: Soil and Water Conservation in China [M]. Beijing: Science Press, 2004 In Chinese

[2] L. Chen: Chinese Soil and Water Conservation, (7) :4-6 (2002) In Chinese

[3] J.E. Gao, P.T. Wu, W.Q. Niu: J. Agr. Eng, 21 (10): 41-45 (2005) In Chinese

[4] S.Q. Li, J.E. Gao: Soil and Water Conservation. 18 (1): 6-12 ( 2010 ) In Chinese

[5] H.W. Zhang, X.Z. xu, T. Wu: Yellow River, 28 (1):4-5 ( 2006 ) In Chinese

[6] X. Z. Xu: Soil and Water Conservation, 19 (1):25-27 ( 2005 ) In Chinese

[7] K. Jing: erosion of environmental characteristics and trends of the middle reaches of the Yellow River [M]. Zhengzhou: Yellow River Water Conservancy Press, 1997 In Chinese

[8] W.Y. Yao: Hydraulic Erosion Process and simulation [M]. Zhengzhou: Yellow River Water Conservancy Press, 2001 In Chinese

[9] R • Laer, Soil Erosion Research Methods [M] Beijing: Science Press, 1991

[10] Z.B. Li: the small watershed sediment yield model loess slope [D]. Shaanxi Institute of Mechanical doctoral dissertation, 1991 In Chinese

[11] D.S. Jin: phological experiment and simulation [M] Beijing: Seismological Press, 1995 In Chinese

[12] W.C. Moldenhauer: Transactions, American Society of Agr Eng, 8(1):30-35 ( 1965 )

[13] J.P. Mamisao Development of agricultural watershed by similitude [D]. M.Sc.Thesis, Iowa State College:10- 30 ( 1952 ) .

[14] D.L. Chery: Construction, instrumentation, and preliminary verification of a physical hydrological model[R].USDA-ARS and Utah State Univ. Water Research Lab. Report. Logan, Utah, USA: 5-10 ( 1965 ) . 